\title{
Lithofacies-influenced ostracod associations in the middle Ordovician Bromide Formation, Oklahoma, USA
}

\author{
MARK WILLIAMS ${ }^{1} \&$ DAVID J. SIVETER \\ Department of Geology, University of Leicester, Leicester LE1 7RH, UK. \\ '(Present address: British Geological Survey, Keyworth, Nottingham NG12 5GG, UK.)
}

\begin{abstract}
The Bromide Formation of southern Oklahoma was deposited in a linear basin and on the adjoining platform during a marine transgressive-regressive event in the middle Ordovician. The formation displays wide lateral (platform-basin) and vertical (transgressive-regressive) sedimentary facies variation. From the prolific and diverse ostracod fauna present in the Bromide Formation two lithofacies-related ostracod associations can be defined: a geographically and stratigraphically widespread Anisocyamus Association, occupying subtidally deposited marine sediments; and a Leperditella Association, which is restricted to marginal marine cnvironments. The ostracods of the Bromide Formation demonstrate that the group can be utilized in the Ordovician as a tool to help establish palaeoenvironments and diflerentiate palaeoshoreline. J. Micropalaeontol. 15(1): 69-81, April 1996.
\end{abstract}

\section{INTRODUCTION AND GEOLOGICAL SETTING}

This paper aims to assess the relationships between lithofacies patterns and the stratigraphical and geographical distribution of ostracods in the Bromide Formation of Oklahoma, USA.

The Bromide Formation is the youngest of five formations comprising the Simpson Group (Fig. 1: see Decker \& Merritt, 1931) and forms part of the thick intracratonic succession of Ordovician rocks exposed in the Arbuckle Mountains and Criner Hills of southern Oklahoma. The formation is divided into a lower Mountain Lake Member and an upper Pooleville Member and, based on conodont stratigraphy (Sweet \& Bergström, 1976; Ross et al., 1982; Sweet, 1984), is considered of late Whiterockian-early Mohawkian age. In terms of the British Ordovician 'Series" this equates with the late Llandeilo to early Caradoc.

The Bromide Formation was deposited within a major linear basin (the Southern Oklahoma Aulacogen: Shatski, 1946) and on the adjoining platform during a marine transgressive-regressive event (Fig. 2). The formation displays wide lateral (platform-basin) and vertical (transgressive-regressive) facies variation, having marginal marine to basinal types of lithofacies, and contains one of the most prolific and diverse ostracod faunas recorded from the Ordovician of N. America. Some 48 genera and 83 species of ostracods are documented from the formation (Harris, 1957; Williams, 1990), thus providing an appropriate sequence from which to investigate the patterns and possible controls of the distribution of ostracods, particularly with respect to prevailing lithofacies.

Detailed palaeoenvironmental studies of Ordovician ostracods are rare. Several authors (especially Berdan, 1969 , $1976,1984)$ have noted the co-occurring relationship between leperditiocope-dominated ostracod faunas and marginal marine lithofacies in the Lower Palaeozoic in general. Copeland (1982) documented bathymetrically controlled ostracod assemblages from the middle Ordovician Lower Esbataottine Formation of Canada and, on the basis of published work of other authors, attempted to recognize similar assemblages in other $\mathrm{N}$. American sequences, including the Bromide Formation of Oklahoma.

The ostracod faunas of the Bromide Formation were originally documented by Harris (1931, 1957). Subsequent published research has addressed the taxonomy of a few species (e.g. Martinsson, 1960; Levinson, 1961; Guber \& Jaanusson, 1964; Siveter \& Williams, 1988a \& b; Williams \& Siveter, 1989a \& b: Williams \& Jones, 1990: Miller et al.. 1990; Williams \& Vannier, 1995). With the exception of the leperditiocopes the entire ostracod fauna of the Simpson Group has recently been studied (Williams, 1990). Pending full publication of Williams" revised study, with some modifications we have used herein the binomen of previous authors. Where herein the gencric name is placed in inverted commas (e.g. 'Ctenobolbina' inflata Harris, 1957; sec Pl. 1, Fig. 3) we consider the species to belong to a new, as yet unpublished, genus. Where both the generic and specific names (as used by a previous author) are placed in inverted commas (e.g. "Schmidtella affinis" Ulrich sensu Harris, 1957: see Pl. 2, Fig. 5) we consider that both the genus and species are new (see Williams, 1990).

\section{SECTIONS STUDIED AND METHODS}

The ostracods detailed in the present study were recovered from six logged sections which, taken together, embrace the entire Bromide Formation (Fig. 3). The sections are situated in the Arbuckle Mountains and Criner Hills of southern Oklahoma, USA. Section 1 is situated about $5 \mathrm{~km}$ south of Fittstown adjacent US Highway 99 (Fay et al., 1982, measured section 11a). Sections 2 and 3 are situated in Murray County adjacent to Interstate 35 (Fay et al., 1982, measured sections $16 \mathrm{a}$ and $16 \mathrm{~b}$ respectively). Section 4 is situated adjacent to Interstate 35 in Carter County (Fay et al., 1982, measured section 3). Section 5 is situated on the Arbuckle Ranch (formerly the Johnston Ranch), Murray County (Fay et al., 1982, measured section 1). Section 6 is at Rock Crossing, Carter County, Criner Hills (Fay et al., 1982, measured section 15a). These sections were chosen in order to represent a platform-basin transect across the Southern 


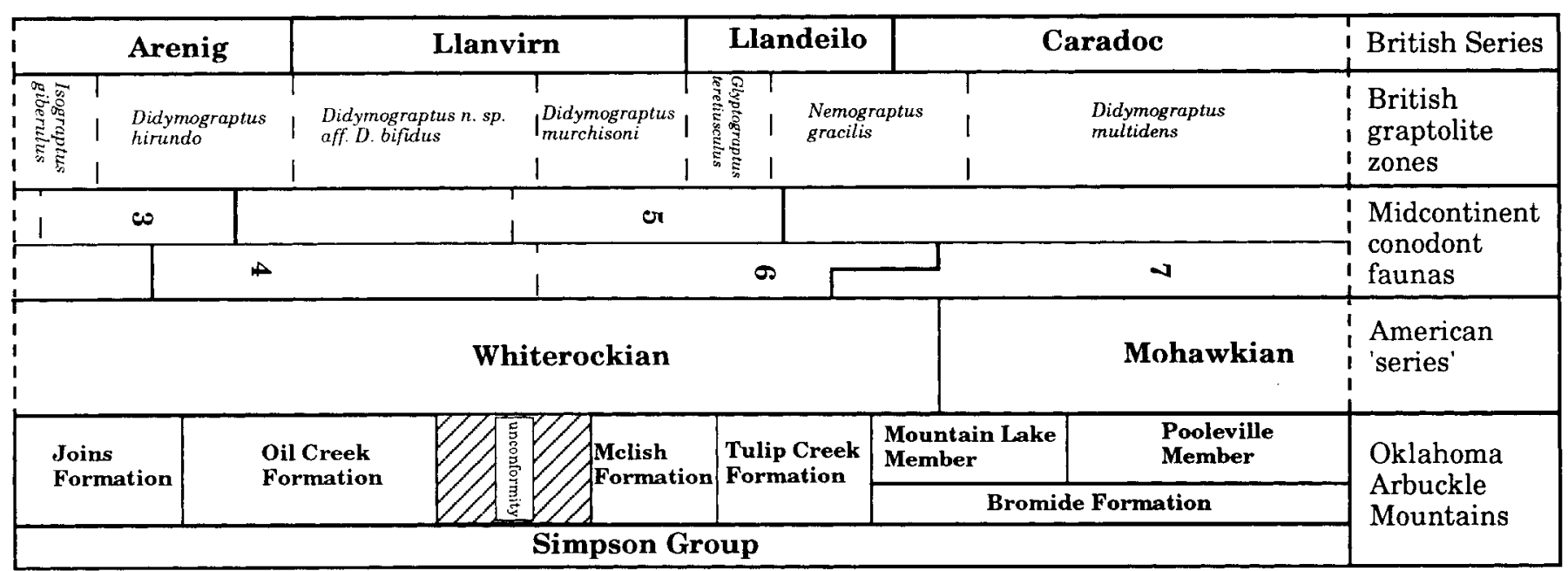

Fig. 1. Stratigraphic setting of the Bromide Formation and its correlation with the 'standard' Ordovician series (adapted from Ross et al., 1982).

Oklahoma Aulacogen. Section 1 is considered to have been situated on the palaeo-platform and section 6 is situated near the centre (i.e. the presumed deepest marine parts) of the palaeo-basin. Sections 2-5 are thought to represent intervening and progressively deeper marine locations down a palaeoslope.

In general, the Mountain Lake Member of the Bromide Formation is well exposed in all 6 sections. The Pooleville Member of the Bromide Formation is well exposed in sections 1,2 and 3; in section 4 only its top few metres is exposed; in section 5 its upper part is incompletely exposed and in section 6 the top of the member is periodically covered by river alluvium.

The ostracod distributions analysed herein are based on faunas recovered from 117 samples collected in the field

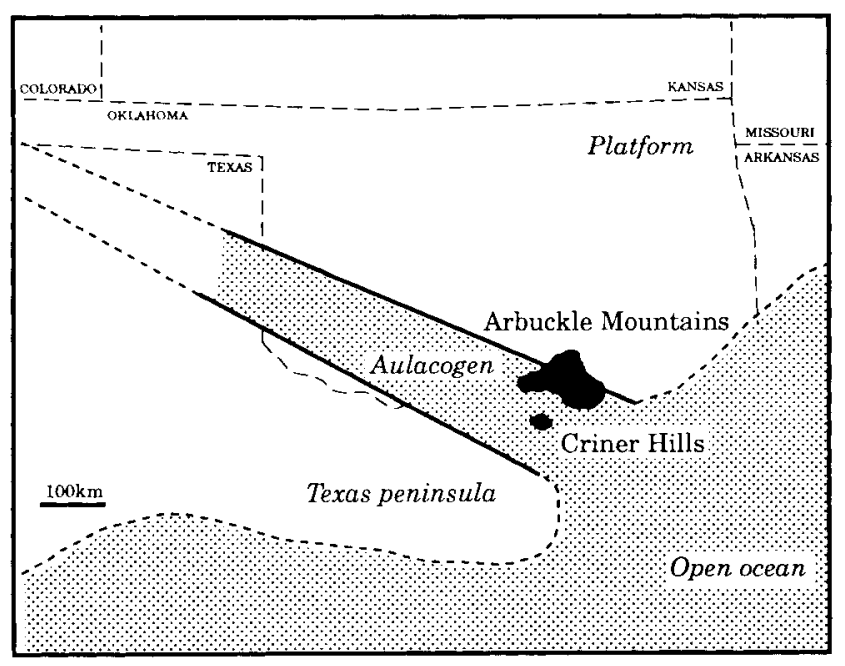

Fig. 2. Palaeogeography of Oklahoma during the deposition of the Bromide Formation (after Longman, 1982).
(Williams, 1990). These samples represent all of the clastic and carbonate lithologies present in the Bromide Formation and, where possible, embrace the whole of the stratigraphic range of the formation exposed in the six sections studied. Section 1 presents the richest and best preserved ostracod faunas so far encountered in the Bromide Formation.

The ostracods of sections 1 and 6 were originally studied by Harris (1957, charts 3 and 4). Harris also studied lateral equivalents of our sections 4 and 5 (see Harris, 1957, charts 2 and 1 respectively). Where appropriate, ostracod data from Harris' collections have been utilized in the present study. Account is also taken of the fact that the stratigraphy of the sections in question has been extensively revised (see Fay et al., 1982; Grahn \& Miller, 1986; Williams, 1990).

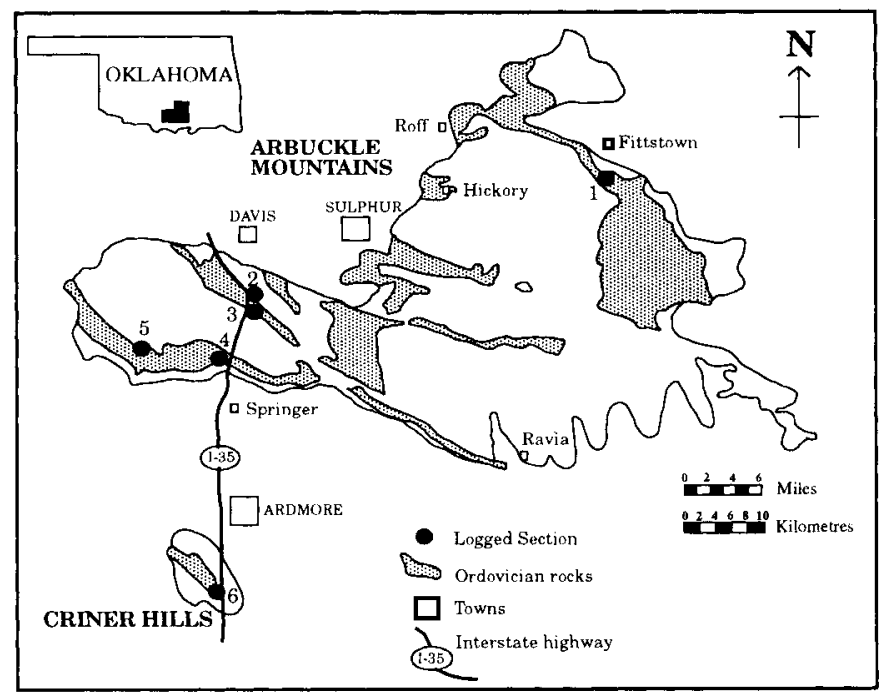

Fig. 3. Location of sections sampled of the Bromide Formation: in the Arbuckle Mountains and Criner Hills, Oklahoma. 
In order to recover ostracods from the Bromide Formation, shale samples were broken down in baths of $10 \%$ hydrogen peroxide and then wet sieved, dried and picked for ostracods. In order to prevent possible bias due to 'facies sampling' the limestones were also sampled in bulk, subsequently broken into small pieces in a rock crusher and then examined for ostracod valves. Specimens recovered in this way were prepared using a vibrotool.

\section{SEDIMENTOLOGY AND PALAEOENVIRONMENTS}

Longman $(1976,1981,1982)$ clearly demonstrates a range of lithofacies in the Bromide Formation which, taken together, indicate a marine transgressive-regressive event (Fig. 4). A clastic shoreface sequence at the base of the Mountain Lake Member of the Bromide Formation overlies the subtidally deposited shales of the Tulip Creek Formation. This shoreface sequence is succeeded by subtidally deposited shales and limestones which form the bulk of the Mountain Lake Member. The overlying carbonate-dominated sequence of the Pooleville Member is interpreted as a phase of regression which, on the platform, culminated with the
Lithofacies

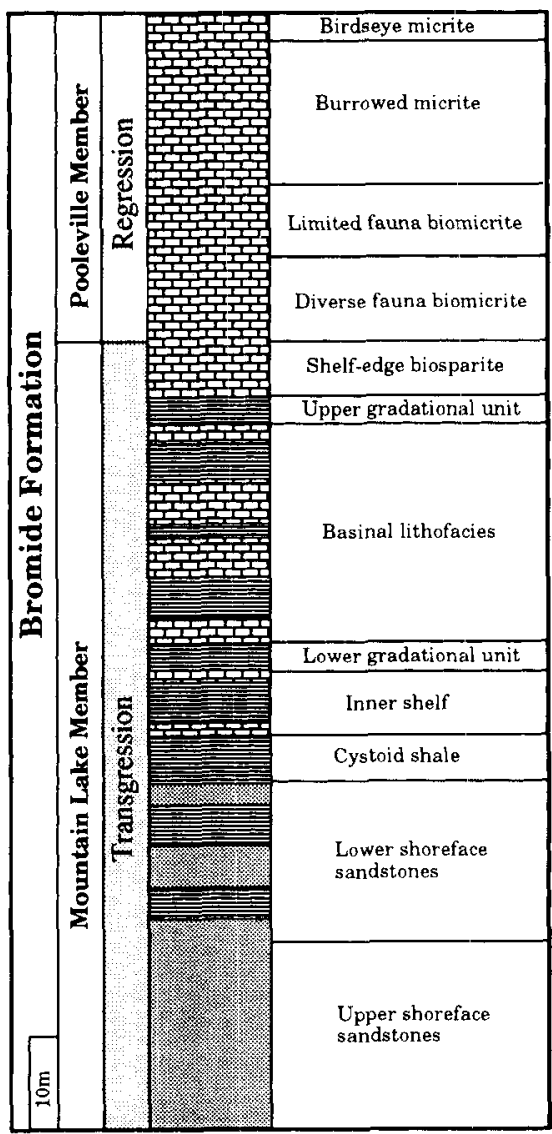

\section{Lithologies}

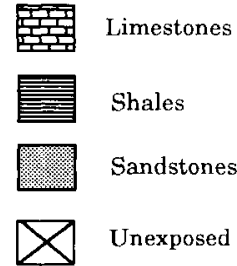

Fig. 4. Composite measured section and summary of lithofacies (after Longman 1982) of the Bromide Formation. The terminology comprises what we would consider a mixture of lithofacies names and terms having environmental implications. In order to relate to Longman's work we herein choose to follow his tcrminology. occurrence of a tidal flat environment. However, ncarer to the geographic and bathymetric depo-centre of the Southern Oklahoma Aulacogen subtidal sedimentation persisted throughout the Pooleville Member.

The sedimentological variation from shelf to basin is discussed below first with reference to sections 1 and 6 , the end-members of the transect. Further data on the relevant lithofacies are given in Longman (1982).

Section 1 (Fig. 5)

This section was situated on the northern palaeo-platform adjoining the Southern Oklahoma Aulacogen (Figs 2, 3). Here, lithofacies of the Bromide Formation are dominantly of shallow marine aspect. The Mountain Lake Member begins with a thick sequence of shoreface sandstones which are succeeded by thin, interbedded, subtidally deposited shales and limestones. Longman (1982) estimated that water depths of only $5 \mathrm{~m}$ prevailed during the acme of the marine transgression represented in this section. The succeeding Pooleville Member is dominated by shallow marine carbonate deposits: these culminate at the top of the sequence with the occurrence of birdseye micrites which are interpreted as the product of deposition in a broad tidal flat environment (Longman, 1982).

\section{Section 6 (Fig. 6)}

Section 6 is situated near the geographic and bathymetric centre of the Southern Oklahoma Aulacogen. Compared to the deposits of section 1, the lithofacies of the Bromide Formation in section 6 have a more deep marine aspect. As in section 1, the sequence begins with shoreface sandstones which are succeeded by interbedded shales and limestones. Longman (1982) estimated water depths of about $80 \mathrm{~m}$ for the acme of the transgression for the strata represented in this section. The lithofacies of the overlying Pooleville Member, comprising richly fossiliferous limestones and shales, show no evidence of regression, and were probably deposited in water depths well below normal wave base.

\section{Sections 2-5}

Sections 2-5 (Fig. 3) represent a gradual, intervening palaeoslope between the depositional settings of sections 1 and 6. Deposits of sections 2 and 3 were situated at the shelf-slope break (hinge line) of the Aulacogen and show a similar development of lithofacies to those of section 1, with regression evident in the Pooleville Member. Deposits of sections 4 and 5 were situated within the more basinal parts of the aulacogen, though apparently in an overall shallower marine setting than those of section 6 . In section 4 the strata of the uppermost Pooleville Member are characterized by birdseye micrites, thus indicating that regression also occurred hore.

\section{OSTRACOD DISTRIBUTIONAL PATTERNS}

A large quantity of data exists concerning the distribution of modern and fossil ostracods in marine environments (e.g. see Whatley \& Maybury, 1990). Modern marine ostracods are predominantly benthic and generally show maximum abundance and diversity in shelf environments. Similar 
Williams \& Siveter

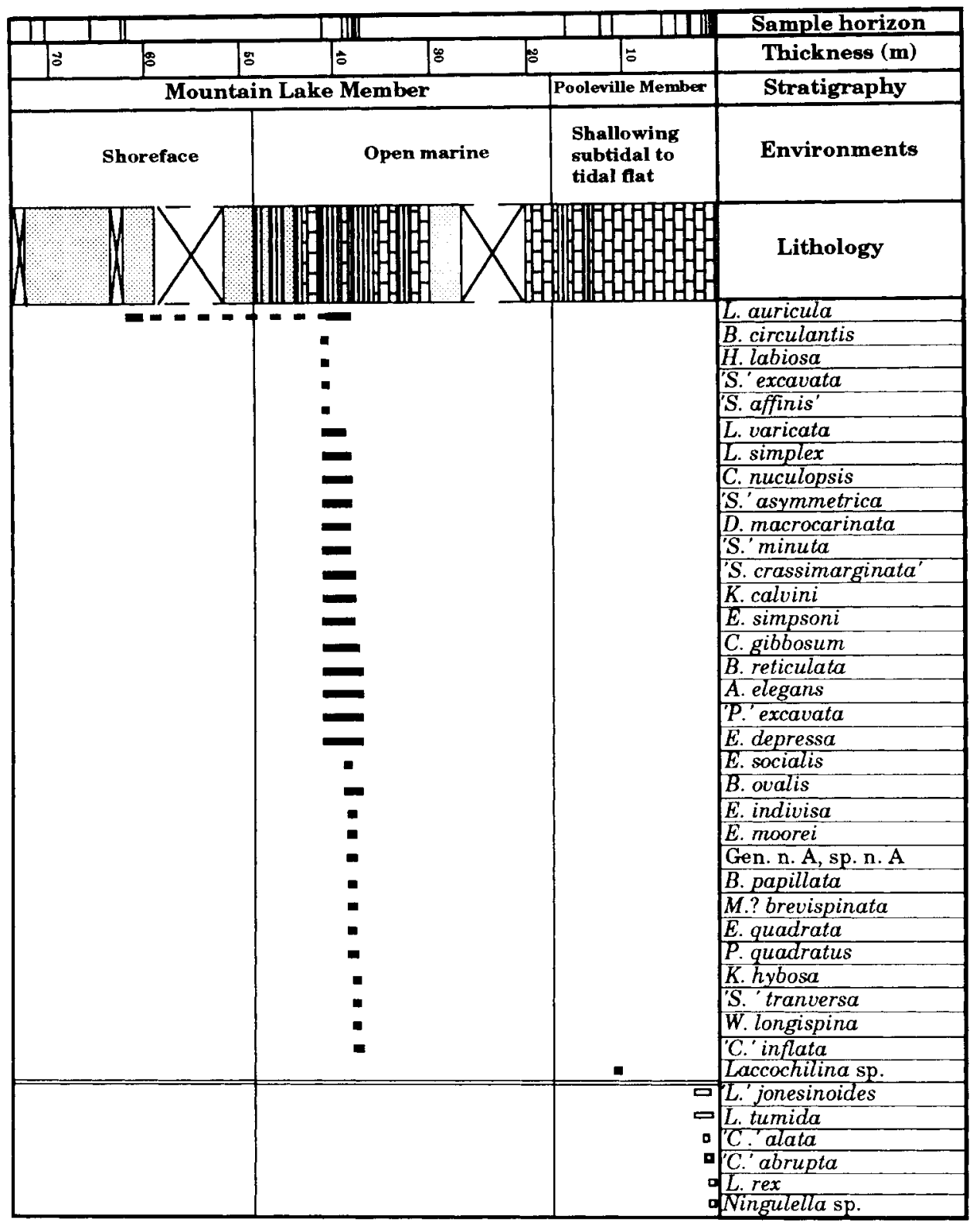

Fig. 5. Stratigraphy, lithology and ostracod ranges for the Bromide Formation at section 1. Anisocyamus Association ostracods are above the double line, Leperditella Association ostracods are below the double line. Log thickness measurements are given in metres from below the contact between the Pooleville Member and the overlying Viola Group as this is an easy datum plane to establish in the field. For key to lithologics sec Fig. 4.

patterns may be expected in the Palaeozoic. For example in summarizing the ecological ranges of Silurian ostracods Siveter (1984) noted that highest diversity among palaeocope-dominated ostracod faunas occurred on the midshelf to shelf upper slope and that reduced diversity was characteristic of both deeper marine and more nearshore high energy environments. A few ostracod taxa (myodocopes) had probably adopted to a pelagic life-style by the Silurian but most Silurian ostracods were apparently benthic (see Siveter, 1984; Siveter et al., 1991).

There are only a few previous attempts at characterizing
Ordovician ostracods in terms of environments and lifestyles. Copeland (1982) identified bathymetrically controlled ostracod assemblages in the middle Ordovician Lower Esbataottine Formation of Canada. He identified two ostracod assemblages: a widespread ostracod fauna ranging from shallow to deeper shelf marine environments and an ostracod fauna restricted to a deeper shelf marine setting. Using published data, Copeland (1982) attempted to recognize similar assemblages in other $\mathrm{N}$. American sequences, including Oklahoma. He compared the ostracod faunas of the Lower Esbataottine Formation to that part of 


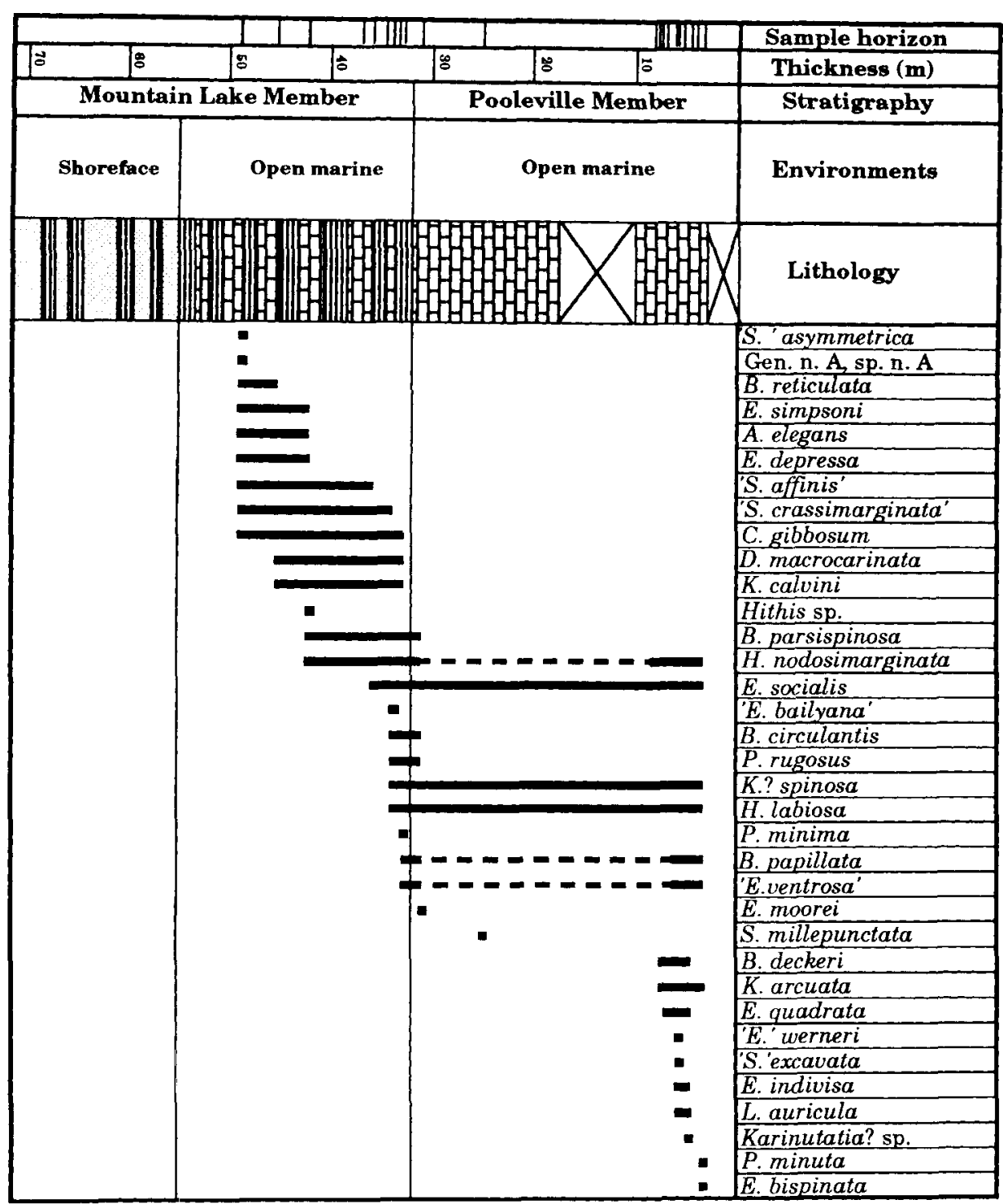

Fig. 6. Stratigraphy, lithology and ostracod ranges for the Bromide Formation at section 6. All ostracods are of the Anisocyamus Association. Log thickness measurements as for Fig. 5. For key to lithologies see Fig. 4.

the Bromide Formation present at the Highway 77 locality (see Harris, 1957). Copeland concluded that the ostracod faunas of the Bromide Formation (Decker's beds 8-15) of the Highway 77 locality (see Harris, 1957) correspond quite closely to the deeper shelf marine ostracod assemblage of the Lower Esbataottine Formation.

Of the 83 ostracod species currently recorded from the Bromide Formation (Williams, 1990), 65 are present in the sections 1-6 discussed herein. The distributional patterns of ostracods in the Bromide Formation is herein presented based on presence/absence data. No statistical analysis has been made, partly in the knowledge that field sample size and sampling interval varied in order to maximize the number of ostracods recovered. Two lithofacies-related associations. of what are presumed to be benthic ostracods, can be clearly recognized within our six sampled sections: the Anisocyamus Association and the Leperditella
Association. The term 'association' is here used with respect to the Bromide Formation for a recurring, discrete group of ostracods which occupy a defined range of lithofacies (palaeoenvironments) and which are taxonomically distinct from ostracod faunas (associations) which occur in other, different lithofacies.

\section{Anisocyamus Association (Pls 1-3; Fig. 7)}

This association, which derives its name from two characteristic primitiopsacean species (Anisocyamus elegans and Anisocyamus bassleri; see Siveter \& Williams, 1988a, b) is present in all six sections (Table 1). The Anisocyamus Association includes the majority of ostracod species (56) documented in the six sections studied and is dominated by palaeocope (see Pls 1-3; Fig. 7) and leiocope ostracods (see Pl. 2). However, overall diversity is high, with eridostracan, binodicope and podocopid ostracod taxa also being 


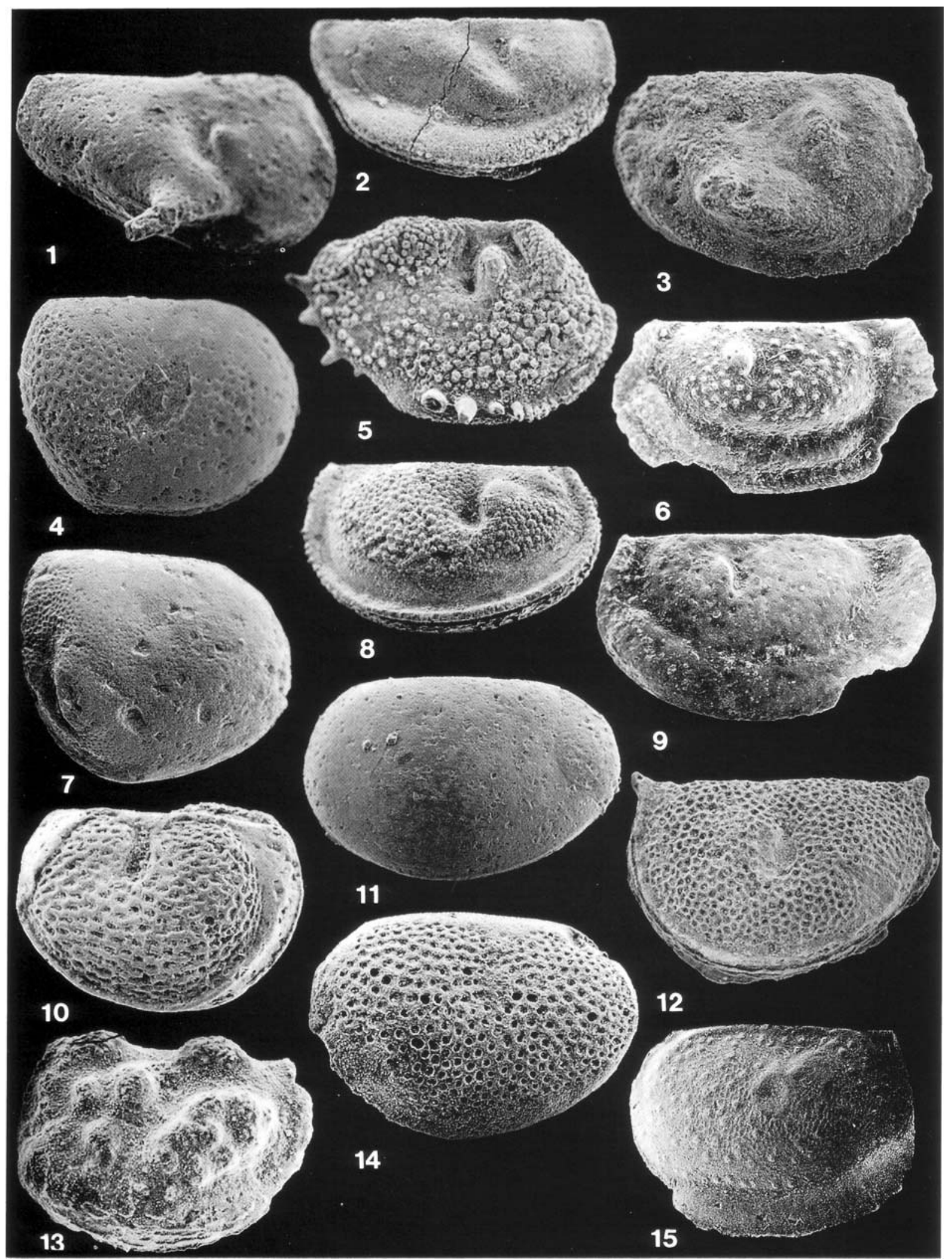

Plate 1 
present (see Pls 2, 3; Fig. 7). Many of the species belonging to the Anisocyamus Association (e.g. Bromidella reticulata, Cryptophyllus gibbosum and Eridoconcha simpsoni) have long stratigraphic ranges, occurring in the Mountain Lake and Pooleville members of the Bromide Formation and also in the underlying Tulip Creek Formation. Within the Anisocyamus Association there also appears to be some cross-basinal variation in the geographical ranges of individual species, although some of this variation may be related to sampling bias in individual sections. A total of seven species (e.g. 'Schmidtella' minuta, Kayina hybosa) appear to be present only in the shallow marine subtidal deposits of section 1. Six species (e.g. Baltonotella parsispinosa, 'Primitiopsis' minuta) appear to be restricted to the deeper marine sediments of section 6 (Table 1). More significantly, however, most species of the Anisocyamus Association have wide geographical distribution; for example, 20 species of this association are common to sections 1 and 6 and a further seven species are common to sections 2 and 6 (Table 1 ).

\section{Leperditella Association (Fig. 7)}

This association, which derives its name from two characteristic leperditellacean species (Leperditella rex and Leperditella tumida), is present only in the upper part of the Pooleville Member and does not occur in all the sections studied. Significantly, the Leperditella Association is absent from section 6. By contrast, the Leperditella Association is best developed, both in terms of species diversity and number of individuals, in section 1. The Leperditella Association is poorly developed in the uppermost part of the Pooleville Mernber at both sections 3 and 4 . The Leperditella Association is characterized by leperditiocope ostracods which occur in limestone beds generally $10-50 \mathrm{~cm}$ in thickness; however, in the intervening shales (generally $2-10 \mathrm{~cm}$ thick), palaeocope ostracods, particularly leperditellaceans, predominate. Significantly, none of the (nine) ostracod species which comprise the Leperditella Association are present in the Anisocyamus Association.

\section{FACTORS INFLUENCING OSTRACOD DISTRIBUTION}

The distribution of the two named ostracod associations is clearly closely related to the distribution of the lithofacies of the Bromide Formation. Deposits of sections 1 and 6 , which record sedimentation on the palaeo-platform and in the palaeo-basin respectively, clearly demonstrate this pattern of occurrence (Figs 5, 6). The most characteristic ostracods recorded from these two sections and belonging to the Anisocyamus and Leperditella associations are illustrated in Plates 1-3 and Fig. 7. In section 6 where, after the deposition of the basal shoreface sandstone sequence, sedimentation occurred in a subtidal marine setting throughout the Mountain Lake and Pooleville members, only the Anisocyamus Association is present (Fig. 6; see also Harris, 1957, chart 4). The Anisocyamus Association is absent from lithofacies characteristic of very shallow or marginal marine deposition such as are developed in the upper part of the Pooleville Member in sections 1-4. Ostracods of the Anisocyamus Association appear to have tolerated a wide range of water depths; it is estimated that relevant marine subtidally deposited sediments of sections 1 and 6 were deposited in water depths of 5 and $80 \mathrm{~m}$ respectively (Longman, 1982).

By contrast, the Leperditella Association is restricted to lithofacies characteristic of very shallow or marginal marine environments, in that it occurs only in the upper part of the Pooleville Member in the platform sequences. Where deeper water sedimentation persisted throughout the Pooleville Member (i.e. section 6, Fig. 6) the Leperditella Association is absent. The Leperditella Association seems to be only completely developed where both limestones and shales were deposited (i.e. section 1). Where only limestones are present (i.e. section 4) only leperditiocope ostracods are present (data of Harris, 1957, chart 1). This suggests that in addition to water depth, substrate was also a factor influencing the distribution of the Bromide Formation ostracods.

The Leperditella Association (comprising nine species)

\section{Explanation of Plate 1}

Figs 1-15. Anisocyamus Association (partim; see also Pls 2, 3; Fig. 7). Palaeocopes: primitiopsaceans (Figs 4, 7, 14), curychilinaceans (Figs 6, 9, 12, 15) and hollinaceans (Figs 1-3, 5, 8, 10, 11, 13). All specimens from the Bromide Formation, Simpson Group, middle Ordovician, Oklahoma, USA. Fig. 1. Winchellatia longispina Kay, 1940. Heteromorphic right valve, lateral view, $\times 57$; BMNH OS13472. From the Pooleville Member, section 1. Fig. 2. Hithis sp. Right valve lateral view, $\times 50$; BMNH OS13517. From the Mountain Lake Member, section 6 . Fig. 3. 'Ctenobolbina' inflata Harris, 1957. Right valve lateral view, $\times 56$; BMNH OS13519. From the Mountain Lake Member, section 1. Fig. 4. 'Primitiopsis' minuta Harris, 1957. Heteromorphic carapace, right valve lateral view, $\times 71$; BMNH OS13503. From the Pooleville Member, section 6. Fig. 5. Bromidella reticulata Harris, 1931. Heteromorphic right valve, lateral view, $\times 42 ;$ MCZ4630. From Decker's bed 36 (see Harris, 1957), section 1. Fig. 6. Eurychilina indivisa Levinson, 1961. Hetermorphic left valve, lateral view, $\times 21$ : USNM139583. From Levinson's zone 11 h (see Levinson, 1961), section 6. Fig. 7. 'Primitiopsis' excavata Harris, 1957. Right valve lateral view, $\times 56$; BMNH OS13505. From the Mountain Lake Member, section 1. Fig. 8. Bromidella papillata (Harris, 1957). Tecnomorphic carapace, right valve lateral view, $\times 32$; MCZ4626. From Decker's bed 3 (see Harris, 1957), section 6. Fig. 9. 'Eurychilina' werneri Levinson, 1961. Heteromorphic left valve, lateral view, $\times 32$; USNM139587. From Levinson's zone 11 (see Levinson, 1961), section 6. Fig. 10. Hallatia labiosa (Ulrich, 1894). Tecnomorphic carapace, left valve lateral view, $\times 62$; MCZ4592. From Decker's bed 9, Highway 77 locality (see Harris, 1957). Fig. 11. Eoaquapulex socialis (Levinson, 1961). Tecnomorphic left valve, lateral view, $\times 42$; BMNH OS13526. From the Pooleville Member, section 6. Fig. 12. Eurybolbina bispinata (Harris, 1957). Juvenile carapace, left valve lateral view, $\times 75 ;$ MCZ4607. From Decker's bed 3 (see Harris, 1957), section 6. Fig. 13. Eohollina depressa (Kay, 1940). Heteromorphic left valve, lateral view, $\times 69$; BMNH OS13543. From the Mountain Lake Member, section 1. Fig. 14. Anisocyamus elegans (Harris, 1957). Heteromorphic carapace, right valve lateral view, $\times 62$; BMNH OS13501. From the Mountain Lake Member, section 1. Fig. 15. Laccochilina sp. Heteromorphic right valve, lateral view, $\times 41$; BMNH OS13513. From the Pooleville Member, section 1. 


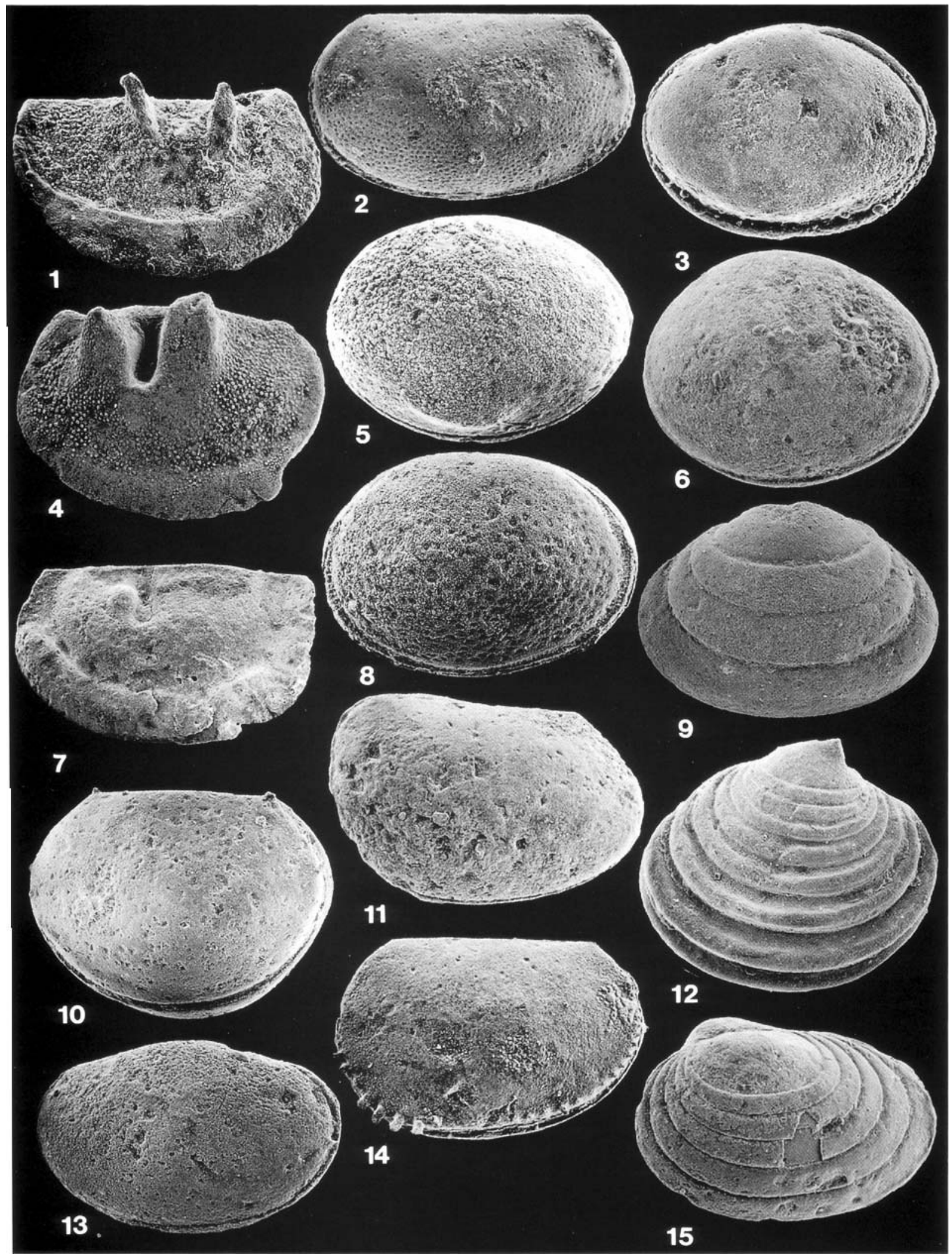

Plate 2 
and the Anisocyamus Association (comprising 56 species) of the six sections studied in the Bromide Formation have no ostracod species in common. The Leperditella Association presumably represents a fauna specifically adapted to marginal marine environments from which the Anisocyamus Association was apparently ecologically excluded (Fig. 8).

The ostracod associations of the Bromide Formation can be compared with Copeland's (1982) middle Ordovician ostracod assemblages from the Lower Esbataottine Formation of Canada. The Lower Esbataottine Formation appears to have been deposited entirely within a marine subtidal setting (Copeland, 1982, p. 4). There are no marginal marine, peritidal or tidal flat depositional environments in the Lower Esbataottine Formation comparable to those of the Bromide Formation in Oklahoma. Correspondingly the Leperditella Association, which in the Bromide Formation is characteristic of lithofacies indicative of marginal marine environments, shows no relationships to the ostracod assemblages of the Lower Esbataottine Formation. By contrast, the Anisocyamus Association of the Bromide Formation has species in common with both the two ostracod assemblages of the Lower Esbataottine Formation. For example, Eurybolbina bispinata (PI. 1, Fig. 12) is common to the Anisocyamus Association of the Bromide Formation and Copeland's (widespread shallow to deeper shelf marine) ostracod assemblage 1. Eohollina depressa (PI. 1. Fig. 13) and Platyrhomboides quadratus (Fig. 7j) are common to the Anisocyamus Association and Copeland's (deeper shelf marine) ostracod assemblage 2. Copeland (1982) compared the Bromide Formation ostracod faunas of Harris (1957) with his assemblage 2 ostracod fauna (deeper shelf marine); it seems that the equivalent of Copeland's Lower Esbataottine Formation ostracod assemblages cannot be clearly differentiated in the Bromide Formation and may be represented in the geographically widespread Anisocyamus Association.

\section{CONCLUSIONS}

Analysis of the geographical and stratigraphical occurrences of ostracods in the Bromide Formation implies the following patterns of their distribution and lithofacies correlation:

1. Ostracod faunas of the Bromide Formation can be characterized in terms of two associations which can be correlated with the distribution of their associated lithofacies. In sequences where subtidally deposited sediments prevail (i.e. section 6) only the Anisocyamus Association is present. However, at localities where sediments deposited in both subtidal and marginal marine environments occur (i.e. section 1) both the Anisocyamus and Leperditella associations are present but are mutually exclusive, the Anisocyamus Association characterizing the subtidal and the Leperditella Association the marginal marine environments.

2. Ostracod faunas, like the Leperditella Association, rich in leperditiocopes and leperditellacean palaeocopes, are present in marginal marine lithofacies in the underlying Joins, Oil Creek and Mclish formations of the Simpson Group in Oklahoma (Williams, 1990). Such ostracod taxonomic groups are also recorded from similar ecological settings in the Silurian (Siveter, 1984). Thus, certain Ordovician and Silurian ostracod faunas appear to be useful tools for predicting proximity to palaeoshoreline and, therefore, may be used as an aid in the reconstruction of palaeogeography.

3. The Anisocyamus and Leperditella associations are broad indicators of palaeoenvironment in the Bromide Formation, describing marginal marine and marine subtidal depositional environments respectively. Ostracod species from both associations, particularly the Anisocyamus Association, occur in other middle Ordovician $\mathrm{N}$. American sequences such as the Edinburg and Lincolnshire formations of Virginia, USA and the Lower Esbataottine Formation of the District of MacKenzie, Canada. As such these species may have more

\section{Explanation of Plate 2}

Figs 1-15. Anisocyamus Association (partim: sec also Pls 1, 3: Fig. 7). Palaeocopes: hollinaceans (Figs 1, 4), an eurychilinacean (Fig. 7), leperditellaceans (Figs 3, 5, 11, 13). Leiocopes: aparchitaceans (Figs 2, 6, 8, 10, 14). Eridostracans (Figs 9, 12, 15). All specimens from the Bromide Formation, Simpson Group, middle Ordovician, Oklahoma, USA. Fig. 1. Dicranella bicornis Ulrich, 1894. Tecnomorphic right valve, lateral view, ×48; MCZ4623. From Decker's Bed 22 (see Harris, 1957), section 1. Fig. 2. Saccelatia millepunctata (Ulrich, 1892). Carapace, left valve lateral view, $\times 36 ;$ MCZ4507. From Decker's Bed 2 (sec Harris, 1957), section 6. Fig. 3. 'Schmidtella' minuta Harris, 1957. Carapace, right valve lateral view, $\times 83$ : MCZ4543. From Decker's bed 36 (see Harris, 1957), section 1. Fig. 4. Dicranella macrocarinata Harris, 1931. Heteromorphic left valve. lateral view, $\times 38 ;$ MCZ7448. From Decker's bed 8, Highway 77 locality (sec Harris, 1957). Fig. 5. 'Schmidtella affinis' Ulrich, 1894 sensu Harris (1957). Carapace, right valve lateral view, $\times 46$; MCZ4532. From Decker's bed 32, Highway 77 locality (see Harris, 1957). Fig. 6. Baltonotella ovalis (Harris, 1957). Carapace, left valve lateral view, $\times 62$; MCZ4545. From Decker's bed 35 (see Harris, 1957), section 1. Fig. 7. 'Eurychilina ventrosa' Ulrich, 1894 sensu Harris (1957). Heteromorphic left valve, lateral view, $\times 29 ;$ MCZ4629. From Decker's bed 32 (see Harris, 1957), section 1. Fig. 8. Baltonotella circulantis (Harris, 1957). Carapace, left valve lateral view, $\times 46 ;$ BMNH OS13564. From the Mountain Lake Member, section 1. Fig. 9. Cryptophyllus gibbosum Harris, 1957. Right valve lateral view, $\times 53$; BMNH OS13574. From the Mountain Lake Member, section 1. Fig. 10. Baltonotella parsispinosa (Kraft, 1962). Juvenile carapace, left valve lateral view, $\times 45$; BMNH OS13567. From the Pooleville Member, section 6. Fig. 11. Kayina hybosa Harris, 1957. Carapace, right valve lateral view, $\times 52 ;$ MCZ4530a. From Decker's bed 36 (see Harris, 1957), section 1. Fig. 12. Eridoconcha simpsoni Harris, 1931. Left valve lateral view, $\times 66$; BMNH OS13477. From the Mountain Lake Member, section 2. Fig. 13. 'Schmidtella' transversa Harris, 1957. Carapace, right valve lateral view, $\times 78 ;$ MCZ4547. From Decker's bed 34 (see Harris, 1957), section 1. Fig. 14. Hyperchilarina nodosimarginata Harris, 1957. Carapace; left valve lateral view, $\times 54$; BMNH OS13562. From the Mountain Lake Member, section 6. Fig. 15. Cryptophyllts nuculopsis Harris, 1957. Carapace, left valve lateral view, $\times 74 ;$ MCZ4568. From Decker's bed 31. Highway 77 locality (see Harris, 1957). 


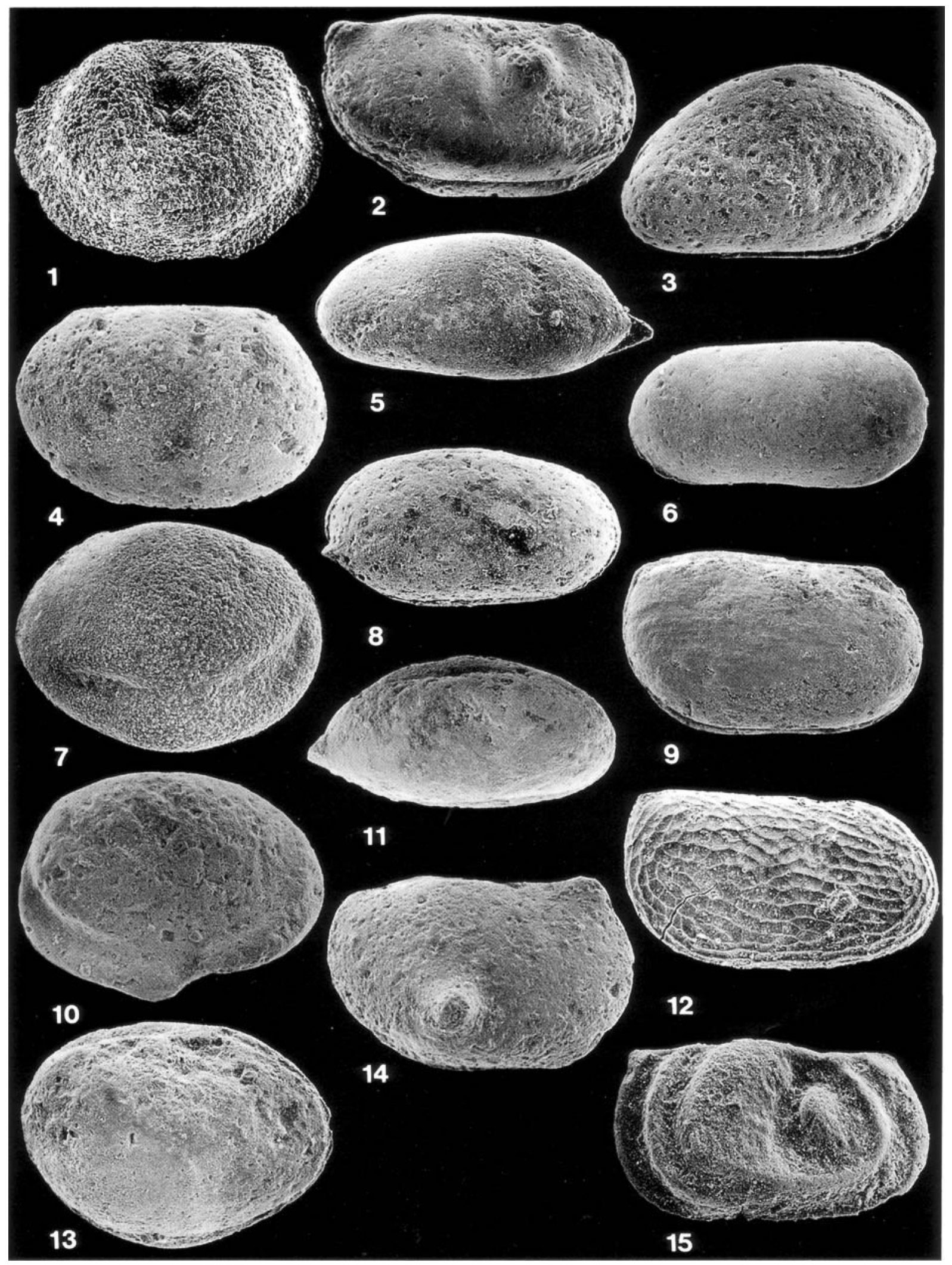

Plate 3 


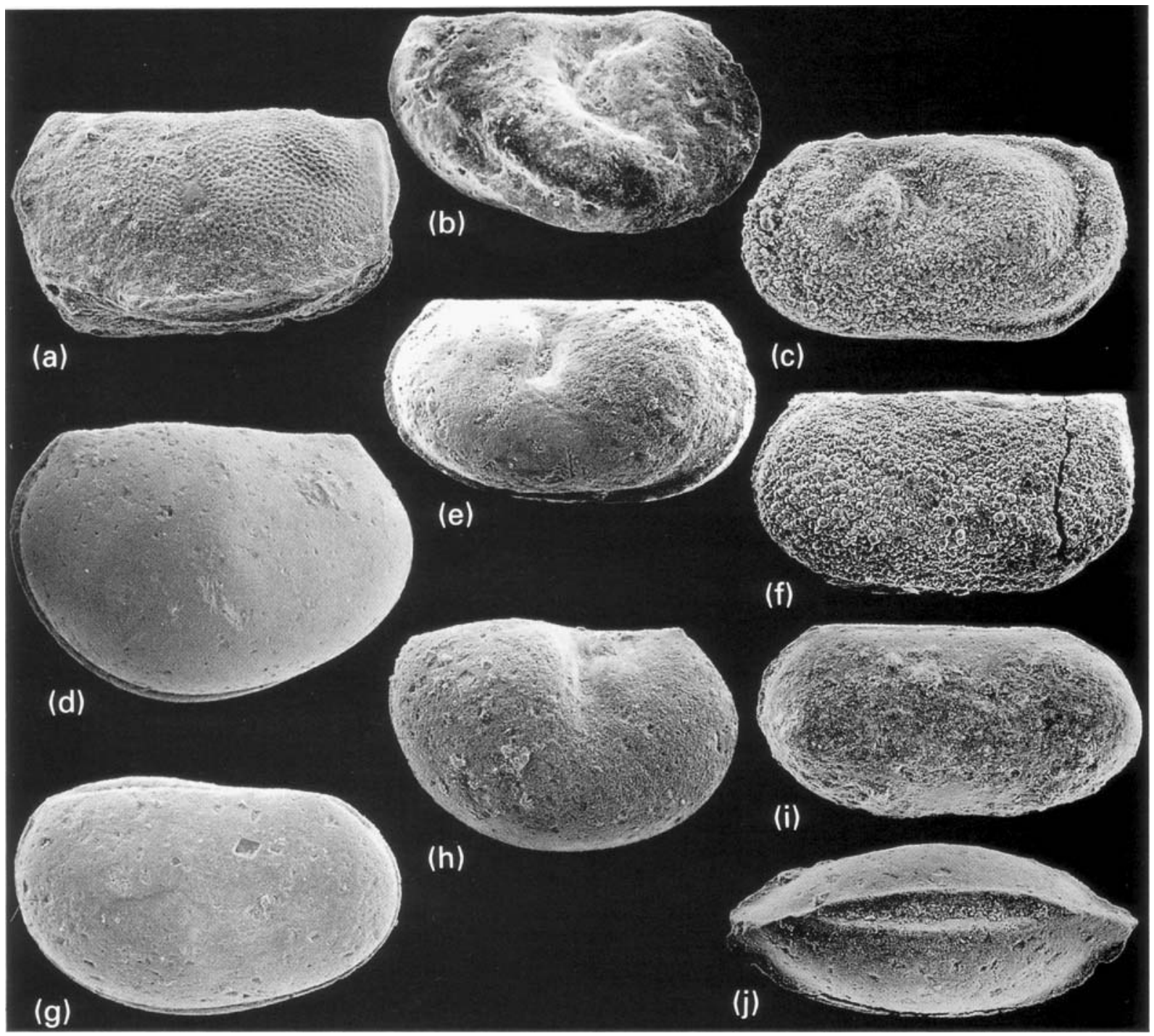

Fig. 7. (c, e, f, j) Anisocyamus Association (partim; see also Pls 1-3). Palaeocopes: lomatopisthids (c, f) and a palaeocope? (e). Podocopid (j). $(\mathbf{a}, \mathbf{b}, \mathbf{d}, \mathbf{g}, \mathbf{h}, \mathbf{i})$ Leperditella Association. Palaeocopes: an eurychilinacean (a), a hollinacean? (b), leperditellaceans (d, g, h) and a monotiopleurid? (i). All specimens from the Bromide Formation. Simpson Group, middle Ordovician, Oklahoma, USA. (a) Coelochilina alata Harris, 1957. Carapace, left valve lateral view, $\times 45 ;$ MCZ4633. From Decker's bed 4 (sce Harris, 1957), section 1. (b) 'Ctenobolbina' abrupta Harris, 1957. Tecnomorphic right valve, lateral view, $\times 62$; BMNH OS13553. From the Pooleville Member, section 1. (c) Lomatopisthia simplex (Harris, 1957). Tecnomorphic left valve, lateral view, $\times 87$. MCZ4641b. From Decker's bed 36 (sec Harris, 1957), section 1. (d) Leperditella tumida Ulrich, 1892. Carapace, right valve lateral view, $\times 28$; MCZ4529. From Decker's bed 4 (see Harris 1957 ), section 1 . (e) Ectoprimitoides moorei (Harris, 1957). Carapace, left valve lateral view, $\times 71$; BMNH OS13630. From the Mountain Lake Member. section 1 . (f) Lomatopisthia varicata (Harris, 1957). Left valve lateral view, $\times 68$ : BMNH OS13611. From the Mountain Lake Member, section 5. (g) Leperditella rex Coryell \& Schenck, 1941. Carapace, right valve lateral view, $\times 65$; MCZ4526. From Decker's bed 4 (see Harris 1957), section 1. (h) 'Leperditella' jonesinoides Harris, 1957. Hetermorphic right valve: lateral view, x39: BMNH OS13596. From the Pooleville Member, section 1. (i) Ningulella sp. Carapace, right valve lateral view, $\times 59$ : BMNH OS13555. From the Pooleville Member, section 1 . (i) Platyrhomboides quadratus Harris, 1957. Carapace, dorsal view, $\times 62 ; \mathrm{BMNH}$ OS13632. From the Pooleville Member, section 6.

\section{Explanation of Plate 3}

Figs 1-15, Anisocyamus Association (partim; see also Pls 1, 2; Fig. 7). Binodicopes (Figs 1, 4). Podocopids (Figs 2, 3, 5, 6, 8, 11, 14). Palaeocopes: leperditellaceans (Figs 7, 10, 13), monotiopleurids (Figs 9, 12) and a lomatopisthid (Fig. 15). All specimens from the Bromide Formation. Simpson Group, middle Ordovician, Oklahoma, USA. Fig. 1. Gen. n. A, sp. n. A. Right valve lateral view, $\times 71 ;$ BMNH OS1.3635. From the Mountain Lake Member, section 1. Fig. 2. Balticella deckeri (Harris, 1931). Carapace, right valve lateral view, $\times 39$; MCZ4636. From Decker's bed 36 (see Harris, 1957), section 1. Fig. 3. Punctaparchites rugosus (Jones, 1858). Carapace, right valve lateral view, $\times 64$; BMNH OS13634. From the Pooleville Member, section 6. Fig. 4. Easchmidtella? quadrata (Harris, 1957). Right valve lateral view, $\times 90 ;$ MCZ4586. From Decker's bed 3 (see Harris, 1957), section 6. Fig. 5. Krausella arcuata Ulrich, 1894. Carapace. left valve lateral view, $\times 33$; BMNH OS13619. From the Pooleville Member, section 6. Fig. 6. 'Eoprimitia bailyana' (Jones \& Holl) sensu Harris (1957). Carapace, right valve? lateral view, $\times 72 ;$ MCZ4649. From Decker's bed 3 (see Harris, 1957), section 6. Fig. 7. 'Schmidtella crassimarginata' Ulrich, 1892 sensu Harris (1957). Left value lateral view, $\times 48$ : BMNH OS13604. From the Mountain Lake Member, section 1. Fig. 8. Krausella? spinosa (Harris, 1957). Carapace, right valve lateral view, $\times 58 ;$ MCZ4652. From Decker's bed 2 (see Harris, 1957), section 6. Fig. 9. Primitiella minima (Harris, 1957). Carapace, right valve lateral view, $\times 62$; MCZ4527. From Decker's bed 24 (see Harris. 1957), section 1. Fig. 10. 'Schmidtella' excavata Harris, 1957. Right valve lateral view, $\times 69 ;$ MCZ4541. Bromide Formation, Mill Creek locality (see Harris, 1957; Williams, 1990). Fig. 11. Kratusella calvini (Kay, 1940). Carapace, right valve lateral view, ×36: MCZ4645. From Decker's bed 26 (see Harris, 1957), section 1. Fig. 12. Karinutatia ? sp. Right valve lateral view, $\times 68$; BMNH OS13597. From the Pooleville Member, section 6. Fig. 13. 'Schmidtella' asymmetrica Harris, 1957. Carapace, right valve lateral view, $\times 84$; MCZ4533. From Decker's bed 31, Highway 77 locality (see Harris, 1957). Fig. 14. Monoceratella? brevispinata Harris, 1957. Right valve lateral view, $\times 39$; MCZ4638. From Decker's bed 36 (see Harris, 1957), section 1. Fig. 15. Lomatopisthia auricula (Harris, 1957). Tecnomorphic right valve, lateral view, $\times 93$; BMNH OS13493. From the Mountain Lake Member, section 1. 


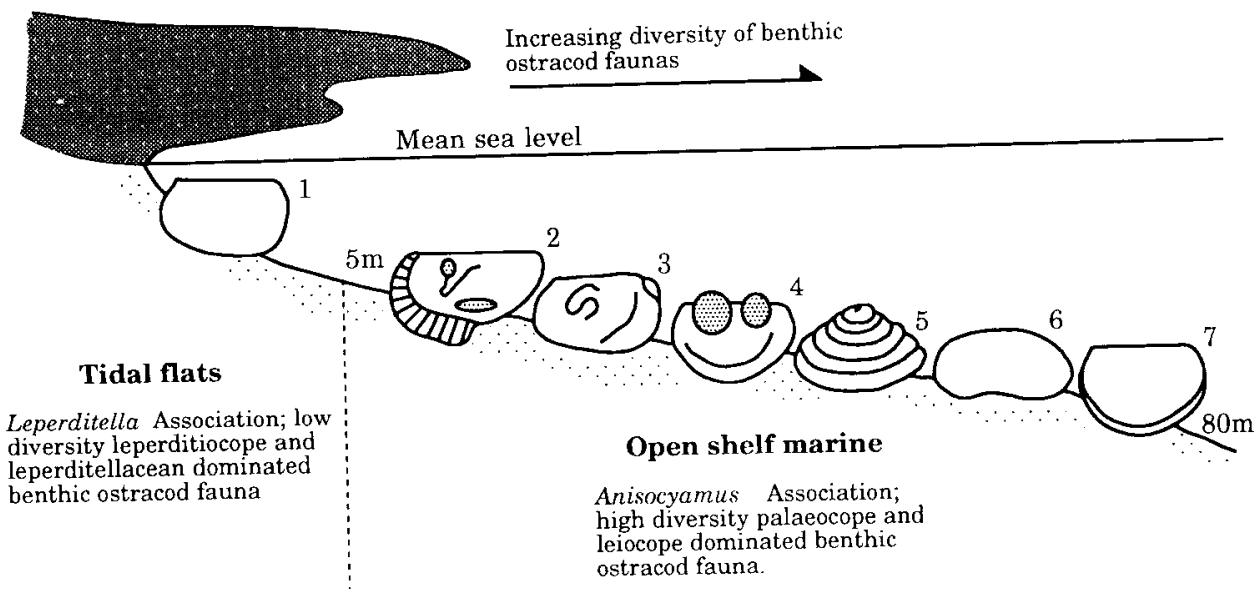

Fis. 8. Schematic representation of the palacocnvironmental relationships of the Anisocyamus and Leperditella associations in the Bromide Fig. 8. Schematic representation of the palacoenvironmental relationships ostracods figured are based on: 1, 'Eoleperditia' inflativentralis: 2 , Winchellatia longispina: 3 , Lomatopisthia Fouricula: 4, binodicope Gen. n. A, sp. n. A; 5, Cryptophyllus gibbosum; 6, Kratsella arcuata; 7, Baltonotella parsispinosa.

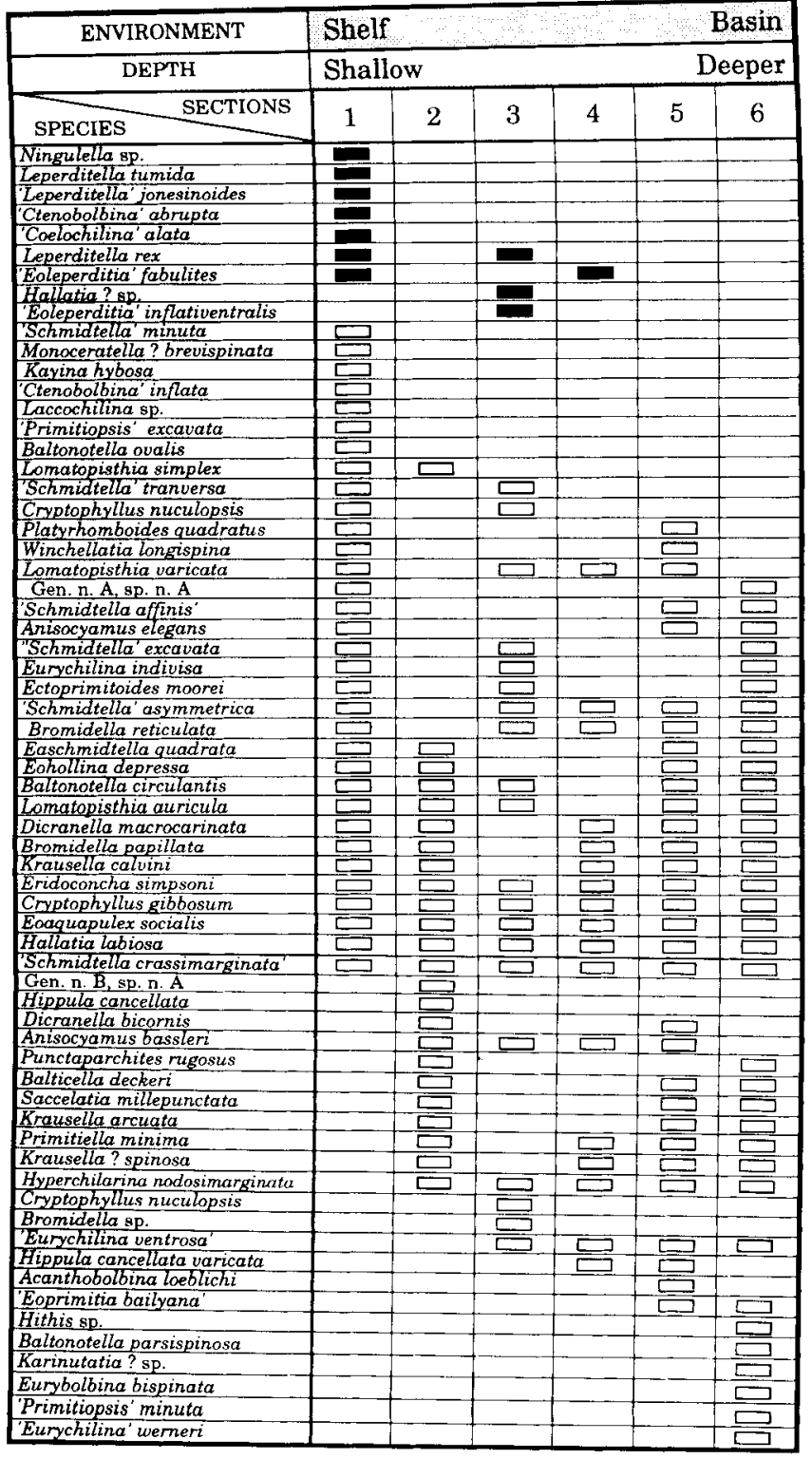

widespread, as yet untested potential use for characterizing palaeoenvironments in the middle Ordovician of $\mathrm{N}$. America.

Repositories for specimens figured in Plates 1-3 and Fig. 7 are: MCZ, Museum of Comparative Zoology, Harvard University, USA: USNM, United States National Museum, Washington DC, USA: BMNH, Natural History Museum, London, UK.

\section{ACKNOWLEDGEMENTS}

M.A. Miller (Amoco, Houston), R.F. Lundin (Arizona State University) and R.O. Fay (Oklahoma Geological Survey) introduced the authors to the geology of the Arbuckle Mountains, B. Weaver (Oklahoma University) and the Pletcher Family (Davis, Oklahoma) provided invaluable help with fieldwork. M. Williams gratefully acknowledges a Natural Environment Research Council studentship (Grant GT4/87/GS/122), during the tenure of which the research for the present paper was undertaken at the University of Leicester. D.J. Siveter gratefully acknowledges support from the NATO collaborative research program (with R.F. Lundin). The text was prepared while M. Williams held an Alexander von Humboldt research fellowship in Germany and France (Universities of Frankfurt and Lyon).

\section{Manuscript received May 1993 Manuscript accepted September 1994}

Note added in proof: Since submission of this paper, Lundin et al. (1995: Journal of Paleontology, 69: 886-896) have referred 'Schmidtella' asymmetrica Harris, 1957 to their new genus Loculocavata.

\section{REFERENCES}

Berdan, J. M. 1969. Possible paleoecologic significance of leperditid ostracodes (abstract). Speciat Paper, Geological Society of America, 121: 337 .

Table 1. Species occurrence in the six studied sections through the Bromide Formation.

Open rectangles represent ostracods of the Anisocvamus. Association (marine subtidal environments). black rectangles those of the Leperditella Association (marginal marine environments). 
Berdan, J. M. 1976. Middle Ordovician Leperditiocopid ostracodes from the Ibex area, Millard County, western Utah. Geology Studies, Brigham Young University, 23: 37-65.

Berdan, J. M. 1984. Leperditiocopid ostracodes from Ordovician rocks of Kentucky and nearby states and characteristic features of the order Leperditiocopa. Professional paper United State's Geological Suney, 1066-j: 1-40.

Copeland, M. J. 1982. Bathymetry of early middle Ordovician (Chazy) Ostracodes, Lower Esbataotine Formation, District of Mackenzie. Bulletin of the Geological Survey of Canada, 347: $1-39$

Coryell, H. N. \& Schenck, H. G. 1941. Type of the Ordovician ostracode genus Leperditella. Journal of Paleontology. 15: 176-177.

Decker. C. E. \& Merrill, C. A. 1931. The stratigraphy and physical characteristics of the Simpson Group. Bulletin of the Oklahoma Geological Survey, 55: $1-112$.

Fay. R. O. Grafham. A. \& Sprinkle. J. 1982. Measured scetions and sampling localities. In Sprinkle. J. (Ed.). Echinoderm faunas from the Bromide Formation (middle Ordovician) of Oklahoma Universiry of Kansas Paleontological Contributions, Monograph. 1: $345-369$.

Grahn. Y. \& Miller. M. A. 1986. Chitinozod from the middle Ordovician Bromide Formation. Arbuckle Mountains, Oklahoma. U.S.A. Neues Jahbuch fïr Geologie und Paläontologic, Abhandlingen, Abteilung $B, 172: 3,381-403$

Guber, A. L. \& Jaanusson. V. 1964. Ordovician ostracodes with posterior domiciliar dimorphism. Bulletin of the Cicological Institutions of the University of Uppsala, 43: 1-43.

Harris, R. W. 1931. Description of Microfauna. In Decker. (. E. \& Merritt, $C$. A. The stratigraphy and physical characteristics of the Simpson Group. Bulletin of the Oklahoma Geological Survey, 55: $87-95$.

Hatris, R. W. 1957. Ostracoda from the Simpson Croup. Bulletin of the Oklahoma Geological Survey, 75: 1--333.

Jones. T. R. 1858. Notes on the Palaeozoic Bivalved Entomostraca. No 4. Some North American Species. Annals and Magazine of Natural History, series 3, 1(4): 241--257.

Jomes, T. R. \& Holl. H. B. 1868 . Notes on the Palacozoic Bivalved Entomostraca. No. 8. Some Lower-Silurian Species from the Chatir of Kildare, Ireland. Annals and Magazine of Natural History, series 4, 2(7): 54-62

Kav. G. M. 1940. Ordovician Mohawkian Ostracoda, lower Trenton Decorah launa. Journal of Paleontology, 14: 234-269.

Kraft, J. C. 1962. Morphologic and systematic relationships of some Middle Ordovician Ostracoda. Geological Society of America. Memoir, 86: 1-104.

Levinson, S. A. 1961. New genera and species of Bromide (middle Ordovician) ostracodes of Oklahoma. Micropaleontologv, 7: $359-364$

Longman, M. W. 1976. Depositional historv, paleoecology and diagenesis of the Bromide Formation (Ordevician). Arbackle Monntains. Oklahoma. PhD thesis, University of Texas. USA

Longman. M. W. 1981. Depostion of the Bromide Formation. Arbuckle Mountains, Oklahoma: ontogeny of an ancient carbonate shelf. Shale Shaker. 32: $1-18$.
Longman, M. W. 1982. Depositional environments. In Sprinkle, J. (Ed.). Echinoderm faunas from the Bromide Formation (middlo Ordovician) of Oklahoma. University of Kansas Paleontological Contributions, Monograph, 1: 17-30.

Martinsson, A. 1960. The primitiopsid ostracodes from the Ordovician of Oklahoma and the systematics of the Family Primitiopsidae. Bulletins of the Geological Institution of the University of Uppsala. 36: 79-105.

Miller, C. G.. Williams, M. \& Wakefield, M. I. 1990. On Bromidella papillata (Harris). Stereo Atlas of Ostracod Shells, 17: 73-76.

Ross, R. J. Jr. ef al. 1982. The Ordovician System in the United States correlation chart and explanatory notes. International Union of Geological Sciences Publication, 12: 1-73.

Shatski, N. S. 1946. The Great Donets Basin and the Wichita System: Comparative tectonics of ancient platforms. Izvestiya Akudemii Nauk SSSR, Seriya Geologischeskaya, 6: 57-90.

Siveter, D. J. 1984. Habitats and modes of life of Silurian ostracodes. In Bassett, M. G. (Ed.), Autecology of Silurian organisms. Special Papers in Palaeonology, 32: 71-85.

Siveter, D. J. \& Williams, M. 1988a. On Anisocyamus elegans (Harris). Stereo Atlas of Ostracod Shells. 15: 107-114.

Siveter. D. J. \& Williams. M. 1988b. On Anisocyamus bassleri (Harris). Slereo Atlas of Ostracod Shells, 15: 115-122.

Siveter, D. J., Vannier, J. M. C. \& Palmer, D. 1991. Silurian myodocopes: pioneer pelagic ostracoda and the chronology of an ecological shift. Journal of Micropalaeontology, 10: 151-175.

Sweet, W. C. 1984. Graphic correlation of upper middle and upper Ordovician rocks, North American Midcontinent Province. U.S.A. In Bruton, D. L. (Ed.), Aspects of the Ordovician System. Palacontological Contributions from the University of Oslo, 295: $23-35$.

Sweet. W. C. \& Bergström. S. 1976. Conodont biostratigraphy of the middle and upper Ordovician of the United States Midcontinent. In Bassett, M. G. (Ed.). The Ordovician System. University of Wales Press and the National Muscum of Wales, $121-151$.

Ulrich, E. O. 1892. New Lower Silurian Ostracoda, No. 1. American Geologist, 10: 263-270.

Uhich, F. O. 1894. The Lower Silurian Ostracoda of Minnesota. Geological and Natural History Survey of Minnesofa, 3: 2 , $1892-1896$ (1897): 629-693.

Whatley, R.C. \& Maybury, C. 1990). Ostracodo and glohal events. British Micropalacontological Society Publication Series. Chapman \& Hall. London.

Williams. M. 1990. Ostracoda (Arthropoda) of the middle Ordovician Simpson Group, Oklahoma, USA. PhD thesis. University of Leicester. UK.

Williams, M. \& Siveter, D.J. 1989 a. On Bromidella reticulata Harris. Sitereo Atlas of Ostracod Shells, 16: 1-8.

Williams, M. \& Siveter, D.J. 1989b. On Balicella deckeri (Harris) Steres Allas of Ostracod Shells, 16: 94-99.

Williams, M. \& Jones, P.J. 1990. On Eridoconcha simpsoni Harris. Stereo Atlas of Ostracod Shells, 17: 13-18

Williams, M. \& Vannier, J.M.C. 1995. Middle Ordovician Aparchitidac and Schmidtellidac: the significance of 'featureless' ostracods. Journal of Micropalaentology, 14: 7-24. 